\title{
ABBREVIATIONS
}

A. I. C. C. All-India Congress Committee, the top organ of the Indian Congress Party

ASU Arab Socialist Union, the United Arab Republic

Caja Agraria Caja de Crédito Agrario, Industrial y Minero (the Bank of Agricultural, Industrial, and Mining Credit, Colombia)

CCG Confederación Colombiana de Ganaderos (The Colombian Cattlemen's Confederation)

CCI Central Campesina Independiente (Independent Peasant Central, Mexico)

CIDA Comité Interamericao de Desarrollo Agrícola (Inter-American Committee for Agricultural Development)

CNC Confederación Nacional Campesina (The National Confederation of Peasants, Mexico)

CNPPA Confederación Nacional de la Pequeña Propiedad Agricola (National Confederation of Small Agricultural Proprietors, Mexico)

CPI The Communist Party of India

CPM The Communist Party of India, Marxist

CPML The Communist Party of India, Marxist, Leninist

CROM Confederación Regional Obrera Mexicana (Regional Confederation of Mexican Workers)

CTM Confederación de Trabajadores de Mexico (Confederation of Workers of Mexico)

EDCOR The Economic Development Corps of the Armed Forces of the Philippines

ELN Ejercito de Liberación Naciondl (The Army of National Liberation, Colombia)

FA Farmers' Association, Taiwan 
FAO

FARC

FUP

GDP

GNP

INCORA

JCRR

KMT

LA

LASEDECO

LNC

LTA

MLA

MNR

MP.

MRL

NAFTAFA

NARRA

NLRC

NLSA

NRPA

PCC

PML

PNA

United Nations Food and Agriculture Organization Fuerzas Armadas Revolucionarias de Colombia (The Colombian Revolutionary Armed Forces)

Frente Unido del Pueblo (The People's United Front, Colombia)

Gross domestic product

Gross national product

Institute Colombiano de la Reforma Agraria (Colombian Institute of Land Reform)

Chinese-American Joint Commission on Rural Reconstruction

The Kuomintang, the Nationalist Party of the Republic of China

Land Authority, the Philippines

The Land Settlement and Development Corporation, the Philippines

Liga Nacional Campesina (National Peasant League, Mexico)

Land Tenure Administration, the Philippines

Members of Legislative Assembly of a state in India

Movimiento Nacional Revolucionario (National Revolutionary Movement, Bolivia)

Members of Parliament (India)

Movimiento Revolucionario Liberal (the Liberal Revolutionary Movement, Colombia)

National Federation of Tenants and Farmers Associations, the Philippines

The National Resettlement and Rehabilitation Administration, the Philippines

National Land Reform Council, the Philippines

The National Land Settlement Administration, the Philippines

National Rice Producers Association, the Philippines

Partido Comunista de Colombia (The Communist Party of Colombia)

Pakistan Muslim League

Partido Nacional Agrarista (National Agrarian Party, Mexico) 
PNR Partido Nacional Revolucionario (The Revolutionary Party, Mexico)

PRI Partido Revolucionario Institucional (Institutional Revolutionary Party, Mexico)

PRM Partido Revolucionario Mexicano or Partido de la Revolucion Mexicana (Mexican Revolutionary Party)

RCC The Revolutionary Command Council (Egypt)

SAC Sociedad de Agricultores Colombianos (The Society of Colombian Agriculturalists)

U. A. R. The United Arab Republic or Egypt

UGOCM Unión General de Obreros y Campesinos de Mexico (General Union of Workers and Peasants of Mexico)

\section{CONVERSION TABLE OF LAND UNITS}
1 hectare
$=2.47109$ acres
1 acre
$=0.40468$ hectare
1 chia (Taiwan) $=0.96992$ hectare $=2.39680$ acres
1 feddan (Egypt) $=0.4201$ hectare $=1.038$ acres

\section{SYMBOLS}

ha.

$\mathrm{M} / \mathrm{T}$

$\mathrm{Kg}$.

$\mathbf{P}$

NT\$

$£ E$

Rs. hectare (s)

metric ton

kilograms

peso

New Taiwan dollar

Egyptian pound (currency unit)

Rupee

In Tables

... data not available

magnitude less than $1 / 2$ of the unit employed, or nil

- not applicable 